Hydrol. Earth Syst. Sci. Discuss., https://doi.org/10.5194/hess-2017-678

Manuscript under review for journal Hydrol. Earth Syst. Sci.

Discussion started: 12 January 2018

(c) Author(s) 2018. CC BY 4.0 License.

\title{
Seasonally frozen soil modifies patterns of boreal peatland wildfire vulnerability
}

Simon J Dixon ${ }^{1 *}$; Max C Lukenbach ${ }^{2}$; Nicholas Kettridge ${ }^{1}$; Kevin J Devito ${ }^{3}$; Richard M

Petrone $^{4}$; Carl A Mendoza ${ }^{2}$; J Michael Waddington ${ }^{5}$

${ }^{1}$ School of Geography, Earth and Environmental Sciences, University of Birmingham,

Edgbaston, Birmingham, B15 2TT, UK.

${ }^{2}$ Department of Earth and Atmospheric Science, University of Alberta, Edmonton, AB, T6G

2E3, Canada

${ }^{3}$ Department of Biological Sciences, University of Alberta, Edmonton, AB, T6G 2E9,

Canada

${ }^{4}$ Department of Geography and Environmental Management, University of Waterloo,

Waterloo, ON, N2L 3G1, Canada

${ }^{5}$ School of Geography and Earth Sciences, McMaster University, Hamilton, ON, L8S 4K1,

Canada

* - Corresponding Author: s.j.dixon@bham.ac.uk 


\section{Abstract}

2 Peatlands play a vital role in the global carbon cycle, acting as one of the most important

3 global carbon sinks. However, an understanding of their environmental processes,

4 particularly in relation to a changing climate, remains inchoate. In particular, the role

5 seasonal ice or frost layers play in altering spring water balance, and thus vulnerability to deep smoldering combustion during wildfire is not fully understood. Continental boreal peatlands are characterized by periodic wildfire disturbance, which releases carbon, but can

8 also inhibit short-term peat productivity and carbon sequestration as the peatland recovers,

9 with recovery timescales linked to the severity or depth of burning. The presence of seasonal

10 frost layers coincides with drier spring conditions and an enhanced risk of wildfire. Two-

11 dimensional numerical modelling was conducted using HYDRUS-2D, a variably saturated

12 flow model, to simulate water balance in the vadose zone and assess vulnerability to fire

13 during prolonged rain free periods in the presence of continuous and discontinuous frost.

14 Our results show there is a lack of horizontal water transfer which increases spatial

15 variability in water balance and leads to pronounced heterogeneity in the risk of smoldering combustion and the potential for deep combustion at hummock-hollow interfaces. Peatlands are broadly divided into areas which are characterized by a dry near-surface and high water contents at depth (water conserving), and those with a wetter near-surface, but comparatively lower water contents at depth (productive). Those areas with dry nearsurfaces will be more vulnerable to wildfire and characterize around $50 \%$ of hummocks and

$2125 \%$ of hollows. In the presence of a seasonal frost layer productive peat layers in hollows

22 will show substantial drying out due to the frost layer disconnecting the surface from the

23 water table; this approximately doubles the proportion of hollows vulnerable to wildfire.

24 Breaks in the frost layer allows areas to maintain hydrological connectivity to a falling water

25 table, but this connectivity is limited in lateral extent and can drive further spatial

26 heterogeneity in vulnerability to wildfire ignition in the weeks when the frost layer begins to

27 thaw. 
29 Peatlands are an important global carbon sink (Frolking and Roulet, 2007;Gorham, 1991), accounting for up to $30 \%$ of the total soil carbon pool despite covering $3 \%$ of the global land surface (Gorham, 1991;Smith et al., 2004;Yu et al., 2010). Wildfire is the largest natural disturbance impacting northern peatlands (Stocks et al., 2002) and is increasing in areal extent (Turetsky et al., 2002). From 1960 to 1990, the annual area burnt across boreal North America doubled (Kasischke and Turetsky, 2006), and is projected to increase $118 \%$ by 2100 (Flannigan et al., 2005). Peatland carbon stocks are generally resilient to wildfire, returning to a net carbon sink approximately 13 years post-fire (Wieder et al., 2009). However, there are concerns that increased drying under future climates (Roulet et al., 1992) will increase wildfire severity (Turetsky et al., 2011), potentially transforming peatlands into a net carbon source (Turetsky et al., 2004) and leading to the long term degradation of their carbon stocks (Kettridge et al., 2015b).

41 Smouldering is the dominant form of combustion of peatland carbon stocks (Benscoter et al., 42 2011), with burn depths typically ranging from 0.05 - $0.10 \mathrm{~m}$ (Benscoter and Wieder, 43 2003;Lukenbach et al., 2015b;Shetler et al., 2008;Hokanson et al., 2016). Burn severity and 44 smouldering (measured as depth of burn, DOB) are strongly controlled by the gravimetric water content (GWC) through the peat profile (Prat-Guitart et al., 2016;Benscoter et al., 2011;Lukenbach et al., 2015b). The GWC of peat is a function of water content and peat density, GWC thus determines the balance between a continued energy source to sustain combustion, produced by the burning of peat, and the energy sink (Benscoter et al., 2011;Prat-Guitart et al., 2016). Where GWC is low, small amounts of energy from the combustion of overlying or adjacent peat are sufficient to drive off water held within the peat to propagate smouldering (Benscoter et al., 2011). Therefore, patterns of peat moisture content and bulk density, which control peat GWC, are crucial to determining patterns of smouldering during peatland wildfire. hydraulic conductivity) and atmospheric water demand control the distribution of peat moisture contents in the vadose zone, thereby influencing GWC and peat burn severity.

57 However, boreal and sub-arctic peatlands are also characterised by pronounced seasonality. 
During winter, snow typically covers peat soils in many places that are either completely frozen, or have frost lenses below the surface. Herein, we refer to this seasonally frozen soil as a "frost layer". Following spring snowmelt, frost layers thaw unevenly producing a

61 heterogeneous landscape composed of frost free and frozen profiles (Petrone et al., 2008). In

62 parts of Alberta this prolonged period of frost thawing can last into the summer months due to the insulating effect of the near-surface peat, potentially decoupling peatland vadose zone processes from the saturated zone (Thompson and Waddington, 2013). Decoupling may prevent water lost through evapotranspiration being replenished by limiting the upward capillary flow from the water table, inducing substantial drying of the near-surface. This enhanced drying would coincide with a spring period of heightened wildfire risk in continental boreal peatlands (Stocks et al., 2002) and may enhance early season wildfire burn severity (Turetsky et al., 2011). Seasonal ice dynamics in peatlands not only have the potential to impact carbon loss during combustion, but may also influence the ecological trajectory post disturbance. Wildfire burn severity directly impacts peatland post-fire ecological recovery (Lukenbach et al., 2016), impacting the ability of the peat forming mosses to re-establish. Specifically, the interaction between pre-fire species cover and burn severity have a large influence on post-fire water availability (Lukenbach et al., 2015a, 2016), thereby playing a large role in the recolonization of peat-forming species. Therefore, if seasonal frost layers influence peat burn severity by

77 altering GWCs at the time of wildfire it could change short-term carbon cycling in these

78 landscapes.

79 In this study, we characterise near-surface frozen soil thaw dynamics within an unburned boreal peatland at a high spatial resolution. We simulate the control of this frozen layer on near-surface peat moisture dynamics using HYDRUS 2D, with specific emphasis on the ability of frozen layer to disconnect saturated water stores from the near surface. We assess how this control is modified by gaps within the frost layer, and consider the associated impact on early season wildfire severity and post-fire peatland recovery. The study has three objectives, to; i) use field measurements to characterise changes in the spatial extent of frozen soil at high spatial resolution within a northern peatland from snowmelt until the

87 disappearance of frost, ii) explore how hydraulic properties and frost layer continuity 
interact to drive vertical and lateral transfers of water during prolonged rain free periods of high fire risk, iii) explore how spatial variability in hydraulic properties, peatland microforms and frost layers interact to induce spatial variability in GWC and associated smouldering severity during the exceptionally dry periods which precede wildfires.

\section{Methods}

\subsection{Study site}

Measurements were undertaken within a peatland $\left(55.8^{\circ} \mathrm{N}, 115.1^{\circ} \mathrm{W}\right)$ within the lacustrine clay region of the Utikuma Lake Research Study Area (URSA) in the Boreal Plains ecotone (Devito et al., 2012), which has not burned since 1935 . It is characterized by hummock hollow microtopography, with ground layer vegetation consisting of S. fuscum, S. angustifolium and feather moss. Vascular vegetation cover includes Ledum groenlandicum, Rubus chamaemorus, Maianthemum trifolia, Vaccinium oxycoccus and V. vitus-idea, and the canopy is comprised of black spruce (Picea mariana) with a basal area of $11 \mathrm{~m}^{2} \mathrm{ha}^{-1}$ and an average height of $2.3 \mathrm{~m}$. For a full site description see Thompson and Waddington (2013) .

\subsection{Field Data}

To examine spatiotemporal variations in depth to ice (objective $i$ ), depth to ice was measured bi-weekly along a $50 \mathrm{~m}$ transect every $0.25 \mathrm{~m}$ (to a maximum depth of $0.5 \mathrm{~m}$ ) through the initial stages of the growing season (following snow melt) until no ice was detected (10 May to $22^{\text {nd }}$ July). Depth to ice was measured by pushing a metal rod through the peat profile until solid frozen soil was detected. Near-surface peat moisture content was also measured with a Delta-T theta probe at each point on the transect. Each sampling location was also classified as a hummock or hollow, and the species cover was noted. Further the relative elevation of each position along the transect was determined using a hose level gauge.

\subsection{Numerical Modelling}

\subsubsection{Model Description}

Simulations were conducted using Hydrus-2D (Šimůnek et al., 1999), a two-dimensional finite element model for simulating water flow in a variably saturated and unsaturated medium with the model domain, discretised as a triangular grid. The governing flow equation is a modified version of the Richard's equation: 


$$
\frac{\partial \theta}{\partial t}=\frac{\partial}{\partial x_{i}}\left[K\left(K_{i j}^{A} \frac{\partial h}{\partial x_{j}}+K_{i j}^{A}\right)\right]-S
$$

where $\theta$ is water content, $K$ is hydraulic conductivity, $h$ is pressure head and $S$ is the sink term. Water retention is characterised by the Van Genuchten (1980) model:

$$
\theta(h)=\left\{\theta_{r}+\frac{\theta_{s}-\theta_{r}}{\left(1+(a|h|)^{n}\right)^{m} \theta_{s}}\right\} \quad h<0 h \geq 0,
$$

and:

$$
m=1-\frac{1}{n} \quad n>1
$$

124

where $\theta(h)$ is soil water retention as a function of the pressure head $h, \theta_{\mathrm{r}}$ and $\theta_{\mathrm{s}}$ are the residual water content and saturated water content for the media respectively, $\alpha$ is an empirical parameter related to the inverse of air entry pressure $\left(\mathrm{m}^{-1}\right)$ and $n$ is an empirical parameter for the pore size distribution. Unsaturated hydraulic conductivity $(K)$ is a function of saturated hydraulic conductivity $\left(K_{s}\right)$ and pressure head:

$$
\begin{gathered}
K(h)=K_{s} S_{e}^{L}\left(1-\left(1-S_{e}^{1 / m}\right)^{m}\right)^{2} h<0 \\
K(h)=K_{s}, \text { when } h \geq 0 \\
S_{e}=\frac{\theta-\theta_{r}}{\theta_{s}-\theta_{r}}
\end{gathered}
$$

$S_{e}$ is the effective saturation and $L$ is a dimensionless pore tortuosity parameter (Simunek et al., 1998).

\subsubsection{Modelling domain}

Two modelling domains were constructed to address objectives $i i$ and $i i i$ (regular and microtopography domains). The model domain for objective $i i$ comprised a two-dimensional grid in the $x z$ plane, $5 \mathrm{~m}$ wide and $2 \mathrm{~m}$ thick, with a grid discretisation of $3 \mathrm{~mm}$ and a horizontal stretching factor of 5. During numerical simulations, it was assumed that no flux occurred across frozen layers based on the very low hydraulic conductivity of frozen soil (McCauley et al., 2002). This was implemented to simulate a frozen layer with zero water flux, inactive cells were included within this basic model framework; these rectangular 
geometric objects were situated at a depth of $0.15 \mathrm{~m}$ below the soil surface. The inactive objects are $0.10 \mathrm{~m}$ thickness with a width specified by the modelling scenario. Grid refinements are applied to points at the evaporating surface and point on the upper edge of the geometry representing the frost layer; this refinement yields a finer model grid nearer the atmospheric boundary and around the no flow (frozen) layer, compared to the base of the grid. Moisture contents were recorded at the evaporating surface, and depths of 0.05 , $0.10,0.15$ and $0.50 \mathrm{~m}$.

The model domain for objective iii simulated a peatland microtopography sequence of hummocks and hollows. The model domain was a grid in the $x z$ plane, $5 \mathrm{~m}$ wide. The hummock-hollow surface topography was characterised as a continuous curve from the top of the hummocks to the base of the hollows. The hummock-hollow sequence had an amplitude of $0.4 \mathrm{~m}$ and wavelength of $2 \mathrm{~m}$. The model domain contains a total of 2.5 hummock-hollow sequences. Therefore, the depth from the hummock and hollow surface to the base of the model domain was $1.4 \mathrm{~m}$ and $1.0 \mathrm{~m}$, respectively.

\subsubsection{Boundary and initial conditions}

The initial conditions of the regular model domain were set assuming an equilibrium pressure head through the peat profile. For the planar surface model domain, the starting water table (zero pressure head) was set at a depth of $0.05 \mathrm{~m}$ below the evaporating surface. In the case of the microtopography domain, the water table was set to a depth of $0.05 \mathrm{~m}$ below the lowest point of the hollow. The base and sides of all model domains were set as no flow boundaries and the surface as an atmospheric boundary. A time variable flux was applied to the atmospheric boundary, representing the diurnal variation in evapotranspiration over a 50 day modelling period, assuming no rainfall input (Dixon et al., 2017). We therefore aim to model a prolonged period of potential drying which would typically precede a spring wildfire. For example, within the fire prone regions of the western boreal plain, Canada, between 1922 and 2007, 10\% of the months of May had less than 16 $\mathrm{mm}$ of precipitation, with a minimum of $5.6 \mathrm{~mm}$ (Slave Lake, Environment Canada, 2017). A threshold value for when surface tension inhibits evaporation (hCritA) is employed. Here we apply a value of $400 \mathrm{mb}$ to represent vegetative stress within mosses limiting evaporation (McCarter and Price, 2014). The frost layer is modelled as rectangular blocks in the model domain with all edges set as no flow boundaries; we thus model the frozen layer 
as a static part of the domain without freeze-thaw mechanics. We are therefore modelling the effect of the frost layer only on disconnecting the near-surface of the model domain from the deeper saturated layer. This is an exploratory modelling framework to examine the impact of frost layer disconnection that does not account for the recharge effects of water provided from thawing frost during the model run. The magnitude of this potential daily recharge rate will be determined from observed rates of ice melt and considered in the context of wider modelling assumptions, notably evaporation rate, initial moisture conditions, and hCritA. The modelling results should therefore be seen not in terms of absolute predictions, but rather comparisons in the response, and magnitude of response, between different scenarios.

The microtopography model was 'spun-up' for a period of 200 days to generate realistic starting moisture conditions as using a default of equilibrium pressure heads in HYDRUS generates unrealistically dry hummocks, whereas naturally hummocks are characterised by relatively moist conditions a few centimetres below the surface (Benscoter and Wieder, 2003;Thompson and Waddington, 2013). The spin up period was applying a weekly rainfall recharge to the peat surface equal to moisture lost through evapotranspiration. This spin up achieved a dynamic equilibrium in water contents with a planar water table depth of approximately $0.04 \mathrm{~m}$ from the base of the hollows and higher unsaturated moisture contents in the hummocks (See supplemental material).

\subsubsection{Hydraulic Properties}

Peat hydraulic properties vary across several orders of magnitude (e.g. Hogan et al., 2006; Lewis et al., 2012;Kennedy and Price, 2005;Boelter, 1965;Branham and Strack, 2014;Beckwith et al., 2003;Baird et al., 2008;Baird et al., 2016). These hydraulic properties have a crucial control on the peatland response to evaporation (Kettridge et al., 2015a;Dixon et al., 2017). However, using mean values of these properties in modelling investigations fails to accurately characterise either the average response or a typical range of responses for a given distribution of peat properties (Kettridge et al., 2015a;Dixon et al., 2017). Therefore, we apply a distribution of hydraulic properties reported in Dixon et al [2017], based upon field data collected by Lukenbach et al [2015] and Thompson and Waddington [2008] (Table I). 
201 These data encompass a full range of peat types and properties, from centre of bogs to dense

202 margin peat areas.

203 Kettridge et al [2015] found that the key factors controlling whether a peat profile displayed 204 high surface tensions under evaporation (water conserving) or was able to maintain low surface tensions during evaporative stress (productive) were inverse entry of air pressure $(\alpha)$ and saturated hydraulic conductivity $\left(K_{s}\right)$; where higher $\alpha$ and lower $K_{s}$ correspond to a greater likelihood of peat being water conserving under stress. In this study, due to computational constraints, we conceptually define a vector through hydraulic property space along the axis corresponding to $\alpha$ and $K_{s}$. We define three different combinations of $\alpha$ and $K_{s}$ along this vector to represent profiles across the transition from water conserving to productive, and generate these values for: all peat, just hollows and just hummocks. Values for $\alpha$ and $K_{s}$ applied were the mean, and plus and minus one standard deviation from the mean. Peat hydraulic properties were not varied with depth in the model. Although variations in peat hydraulic properties with depth have been shown (e.g. Sherwood et al., 2013), Kettridge et al. [2015] found only weak dependence on depth for values of $\alpha$ and $K_{s}$. Quinton et al [2008] also showed that $K_{s}$ is dependent on the degree of compaction and decomposition, which does not necessarily show a linear relationship with depth. tension under evaporative stress; defined here as "water conserving". Conversely, high $K_{s}$ and low $\alpha$ readily transport water to the evaporating surface and is defined as "productive" (Table I). We keep values of residual water content $\left(\theta_{r}\right)$, saturated water content $\left(\theta_{s}\right)$, pore tortuosity $(l)$ and $n$ constant. For modelling scenarios with a hummock-hollow sequence we further generate values for $\theta_{s}, l$ and $\mathrm{n}$, as well as values for $\alpha$ and $K_{s}$ (plus and minus one standard deviation) for hummocks alone (Table I). It is important to note that the difference in modelled hydraulic properties between hummocks and hollows is not as great as the difference between the peats classified as water conserving or productive. The hydraulic property type, based on the property distributions, is more important to behaviour than whether the peat is a hummock or hollow. Hydraulic properties have been shown to have a relationship to moss species (McCarter and Price, 2014), however this remains poorly 

relationships in numerical models.

\begin{tabular}{lllrlrl}
\hline Material & $\theta_{r}$ & \multicolumn{1}{c}{$\theta_{s}$} & \multicolumn{1}{c}{$\alpha$} & \multicolumn{1}{c}{$n$} & $K_{s}(\mathrm{~cm} / \mathrm{hr})$ & \multicolumn{1}{l}{$l$} \\
\hline Mean & 0.01 & 0.939 & 1.828 & 1.192 & 18.31 & -1.411 \\
Water Conserving & 0.01 & 0.939 & 2.380 & 1.192 & 16.31 & -1.411 \\
Productive & 0.01 & 0.939 & 0.176 & 1.192 & 20.31 & -1.411 \\
WC Hummock & 0.01 & 0.965 & 14.999 & 1.213 & 16.31 & -1.411 \\
PR Hummock & 0.01 & 0.965 & 0.628 & 1.213 & 20.31 & -1.411 \\
\hline
\end{tabular}

Table I - hydraulic properties of peat used in the modelling scenarios and based on data in Dixon et

\subsubsection{Modelling Design}

235 To examine water flow pathways and the water balance in the presence of continuous and discontinuous frost layers (Objective ii), four different frozen soil geometries were created within the regular model domains: i) a continuous layer of frozen soil/frost across the model width; ii) a $0.5 \mathrm{~m}$ wide gap in the centre of the frost layer; iii) two $0.5 \mathrm{~m}$ wide gaps in the frost layer either side of a central $1 \mathrm{~m}$ wide block of frozen soil; iv) frost free. Mean, water conserving and productive peat hydraulic properties were used to parameterise the peat layers in the four model geometries, giving a total of 12 model scenarios. For Objective iii the hummock-hollow sequence within the microtopography modelling domain was

243 parameterised with different hydraulic properties in the different microtopographical units.

244 Moving from left to right the model domain was parameterised as; a water conserving

245 hummock, a water conserving hollow, a productive hummock, a productive hollow, and a

246 water conserving hummock. The sequence ensures all four possible transitions between

247 hummock and hollow properties are represented in the model domain. The remainder of the

248 model domain was designated as having mean peat hydraulic properties.

249 2.3.6 Model Analysis

250 To assess fire severity, simulated volumetric moisture contents (VMC) were converted to

251 gravimetric water contents:

$$
G W C=\frac{\theta}{\rho}
$$

253 where GWC is gravimetric water content and $\rho$ is the mean density of peat for a given

254 sample. 
A probabilistic approach is taken to estimate the likelihood that the gravimetric water content of given sub-set of peat (Table I) at a given time in a model simulation is lower than a threshold for smouldering wildfires ignition. A normal distribution of gravimetric water contents was calculated, multiplying the VMC by the full normal distribution of peat observed peat densities, given by:

$$
Y \sim N\left(\theta \mu_{\rho}, \theta^{2} \sigma_{\rho}\right)
$$

where $\mathrm{Y}$ is a normal distribution with a mean of $\theta \mu_{\rho}$ and a standard deviation of $\theta^{2} \sigma_{\rho}$. For a given gravimetric water content, in this case corresponding to the threshold for smouldering (GWC $=250 \%$ ), the $\mathrm{z}$ score for a given distribution is computed as:

$$
z=\frac{x-\theta \mu_{\rho}}{\theta^{2} \sigma_{\rho}}
$$

where $x$ is the smouldering threshold. A probability of the gravimetric water content being lower than the threshold for a given point and at a given time is expressed as a cumulative normal distribution function:

$$
P=\frac{\theta^{2}}{\sigma} \frac{1}{\sqrt{2 \pi}} \int_{-\infty}^{x} e^{\frac{(t-(\mu / \theta))^{2}}{2\left(\sigma / \theta^{2}\right)^{2}}} d
$$

The results from Eq. (8) can then be plotted over time as a metric to indicate the probability of deep smouldering as a function of gravimetric water content probability, given the distribution of peat density in a given type of peat.

\section{Results}

\subsection{Ice field measurements}

Shortly after snowmelt, the frost layer largely followed the surface topography at a depth of 0.2-0.3 $\mathrm{m}$ and subsequently retreated slowly as the frozen soil nearest to the surface began to thaw (Figure 1). The frozen layer eventually began to break up and disappear completely over a period of five weeks from $22^{\text {nd }}$ June, when the frost layer is patchy and broken though in places, to $1^{\text {st }}$ August, when the transect was frost free. The recession of the frozen soil layer can be taken as a daily average from $10^{\text {th }}$ May to the start of break up on $22^{\text {nd }}$ June and along with specific yield of average peat properties from our data set, gives an average daily 
Hydrol. Earth Syst. Sci. Discuss., https://doi.org/10.5194/hess-2017-678

Manuscript under review for journal Hydrol. Earth Syst. Sci.

Discussion started: 12 January 2018

(C) Author(s) 2018. CC BY 4.0 License.
Hydrology and

Earth System

Sciences

Discussions

(c) (1)

281

moisture recharge rate of $1.8 \mathrm{~mm} /$ day. During the period of frost break up, sections of frozen soil 1-1.5 $\mathrm{m}$ in length persist whilst the frost in other areas has thawed completely. Although these persistent blocks of frozen soil can be associated with either hummock or hollow microtopography, the frost layer tends to begin to break up earlier in hollows than hummocks. Furthermore, some of the more persistent blocks of frozen soil are in the bases of hummocks. A binomial logistic regression was run on the effects of topography of the presence of frost on $13^{\text {th }}$ July. The Hosmer-Lemeshow test shows the model fits the data well ( $\mathrm{p}=446$ ), with topography predicting presence of frost at a significance level of $\alpha=0.90$ $(\mathrm{p}=0.091)$.

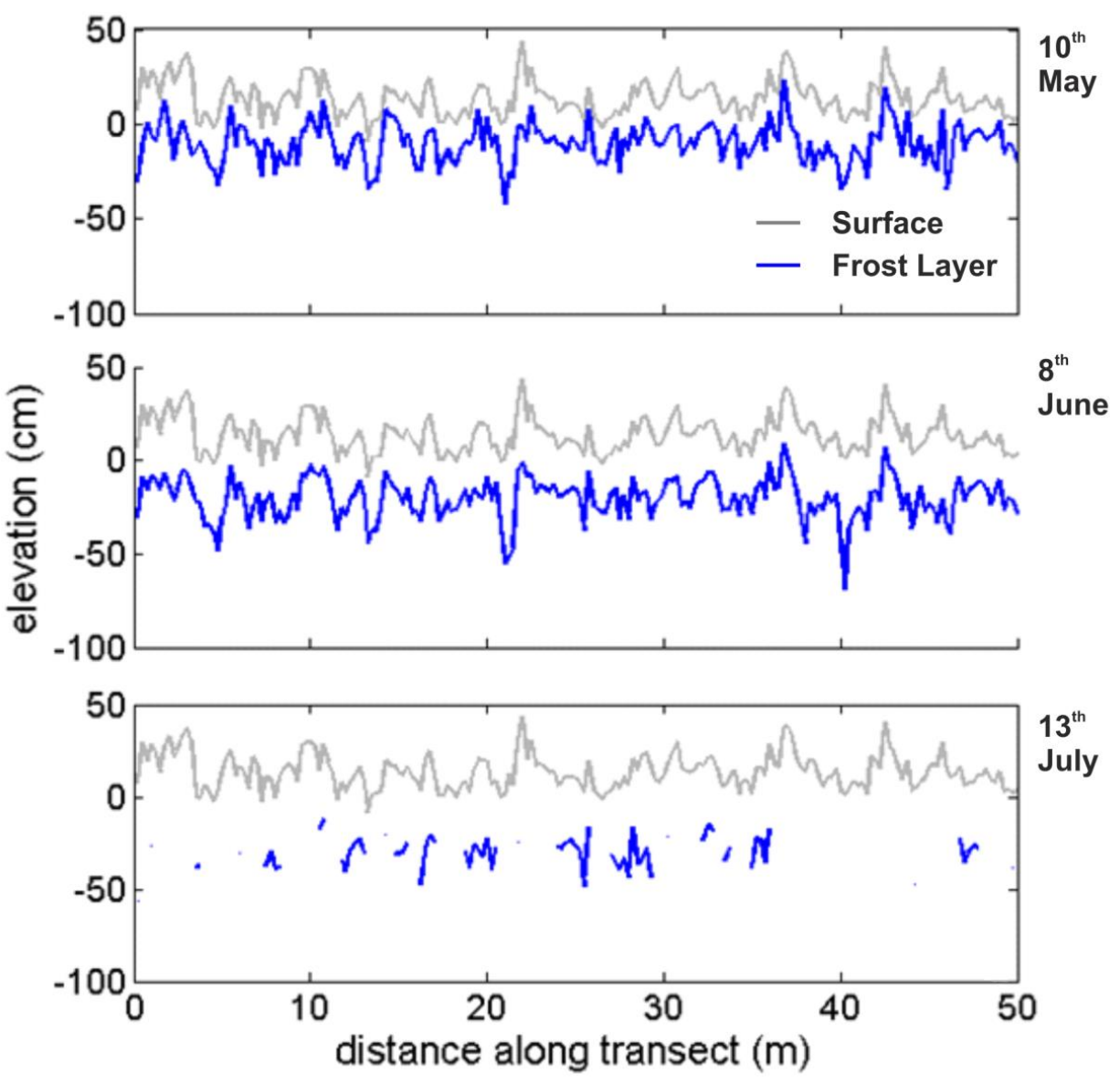

Figure 1 - Field measurements showing surface topography and initial depth to ice (i.e. top of the frost layer) and the breakup of ice into a discontinuous layer later in the season (note the vertical exaggeration in scale). 
Hydrol. Earth Syst. Sci. Discuss., https://doi.org/10.5194/hess-2017-678

Manuscript under review for journal Hydrol. Earth Syst. Sci.

Discussion started: 12 January 2018

(c) Author(s) 2018. CC BY 4.0 License.
Hydrology and

Earth System

Sciences

Discussions

\subsection{2-D model simulations (topography excluded)}

Trends in water content and water movement were strongly associated with whether peat hydraulic properties were "water conserving" or "productive" as well as the continuity of the frost layer. For scenarios with solid frost layers (Figure 2), water is initially lost from the near-surface of the "water conserving" peat via evaporation (Figure 2); within the near surface the volumetric water content (VWC, $\theta$ ) declines to $\sim 0.26$ after three days (Figure 2a) and quickly raises near-surface tensions limiting evaporation. As a result, after a week of evaporation, VMC in the top $0.05 \mathrm{~m}$ of peat profile is low (Figures $2 \mathrm{a}$ and $2 \mathrm{~b}$ ). However, the water table did not drop below $0.10 \mathrm{~m}$ until day 26 (VWC equals the saturated water content of $\theta_{\mathrm{s}}=0.94$; Figure 2c), with a saturated zone remaining above the frozen layer (Figure $2 \mathrm{~d} ; \theta=$ $\left.\theta_{s}\right)$. In comparison, for "productive" combinations of peat hydraulic properties, surface tensions did not rise to levels that limit evaporation. Profiles thus continued to evaporate and the water table dropped to the depth of the frozen layer on day seven of the simulation
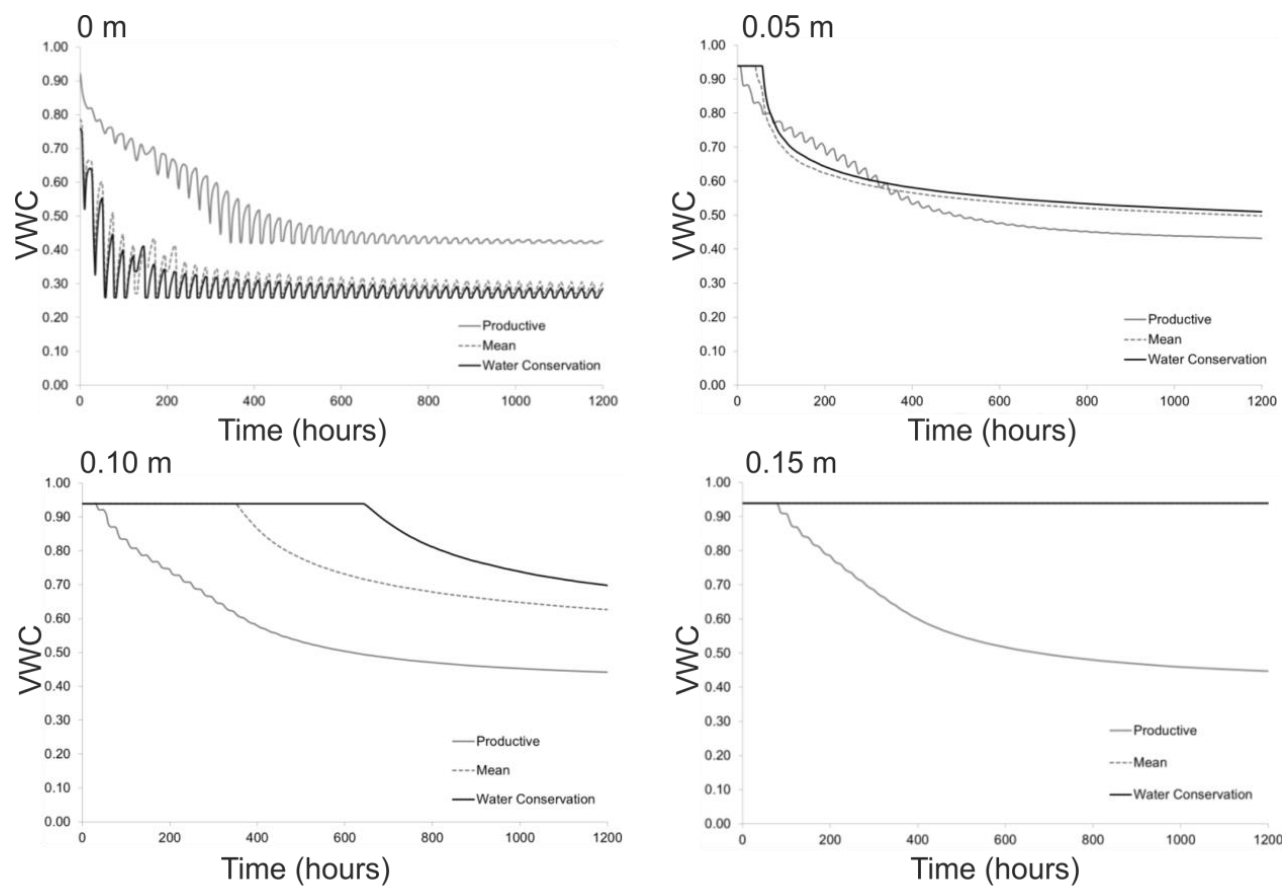

Figure 2 -Volumetric Water Content over time for solid frozen soil layer at $0.20 \mathrm{~m}$ depth. Different panels show VWC at different depths in the peat profile for three different set of peat hydraulic properties; productive, mean and water conserving. 
(Figure 2d; VWC declined after day 7). Thereafter, the VWC in the peat layer above the frost layer continues to decline, as evaporation is sourced from unsaturated zone storage above the frost layer. After three weeks of evaporation, the VMC at $0.15 \mathrm{~m}$ depth is less than 0.50 (Figure 2d).

For scenarios with one or more holes in the frost layer, simulated VMC for the mean and water conservation hydraulic properties are the same as for the solid frost layer. This is because the water table does not drop to the depth of the frost layer during simulations. Therefore, continuity in the frost layer is only important for "productive peat" scenarios (Figure 3). For productive peat, holes in the frost layer result in spatiotemporal variations in water contents and tensions as water is transported to the surface from the saturated peat below the discontinuous frost layer (Figure 3b/c). Once the water table drops below the level of the frost layer, the near-surface peat over a hole in the frost layer is able to maintain a VWC of $\theta \approx 0.50$. However, within the vadose zone, lateral transfer of water supplied through the gap is very limited (Figure 3bc). After five weeks of evaporation there is a clear difference in near-surface VWC between the frozen soil scenarios (Figure 3). The frost free (Figure 3a) and solid frost (Figure 3d) scenarios represent the two extremes in VWC, with the discontinuous frost layer scenarios (Figures 3b/c) showing characteristics of both solid frost and frost free scenarios. Where there is a break in the frozen layer, VWC immediately above the break corresponds to the frost free scenario (Figure 3a). However, a short lateral distance away from the break the VWC in the discontinuous frost scenarios closely resembles the solid frost scenario (Figure 3d).

Once the water table has reached the depth of the frost layer the near-surface peat above the layer does not replace water lost through evaporation and thus peat VWC continues to decline until near-surface water tensions reach $400 \mathrm{mb}$ and evaporation is limited. Conversely, above the breaks in the frost layer the near-surface water tensions remain in the range 150-350 mb over the whole diurnal cycle, indicating that water supplied from deeper saturated peat is able to maintain some evaporation. Consequently, discontinuous frost layers generate heterogeneity in near-surface VWC; $\theta \approx 0.60$ above breaks in the frozen layer compared to $\theta \approx 0.45$ above the frozen layer (Figures $3 b$ and $3 c$ ). 
Hydrol. Earth Syst. Sci. Discuss., https://doi.org/10.5194/hess-2017-678

Manuscript under review for journal Hydrol. Earth Syst. Sci.

Discussion started: 12 January 2018

(C) Author(s) 2018. CC BY 4.0 License.

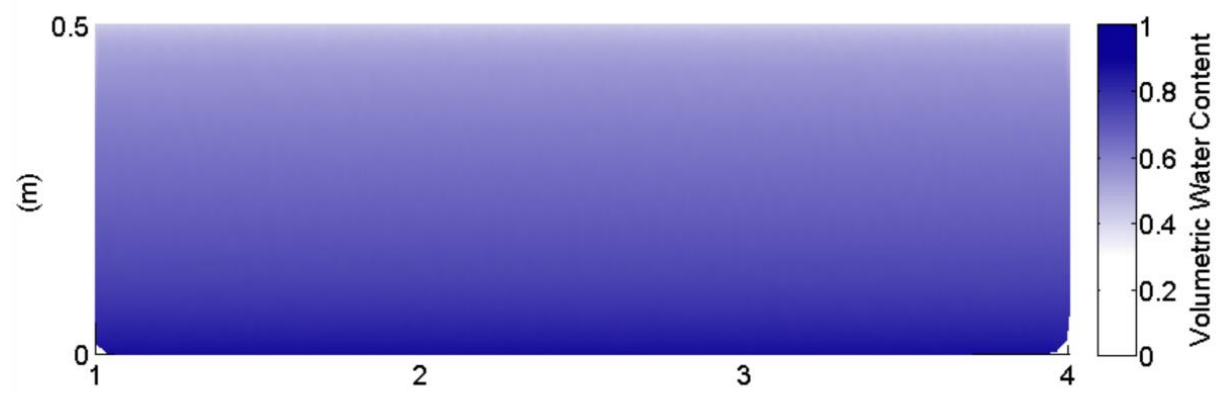

(m)

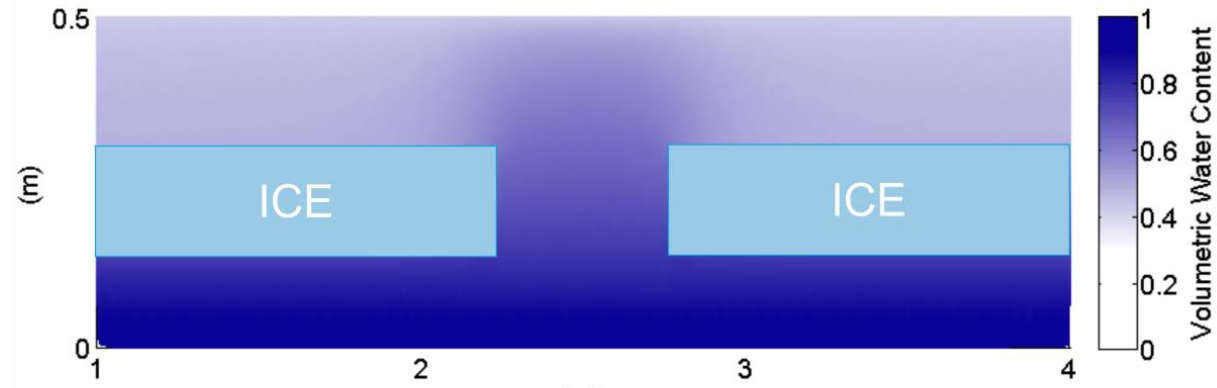

(m)

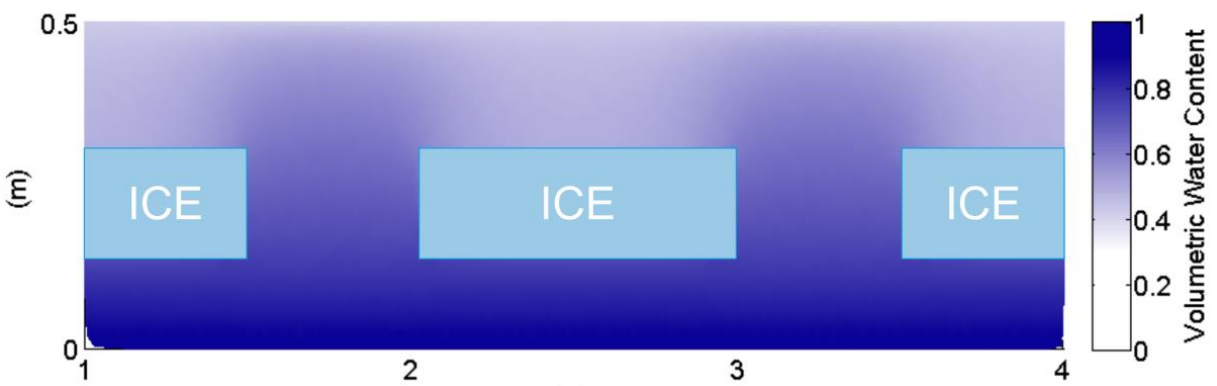

(m)

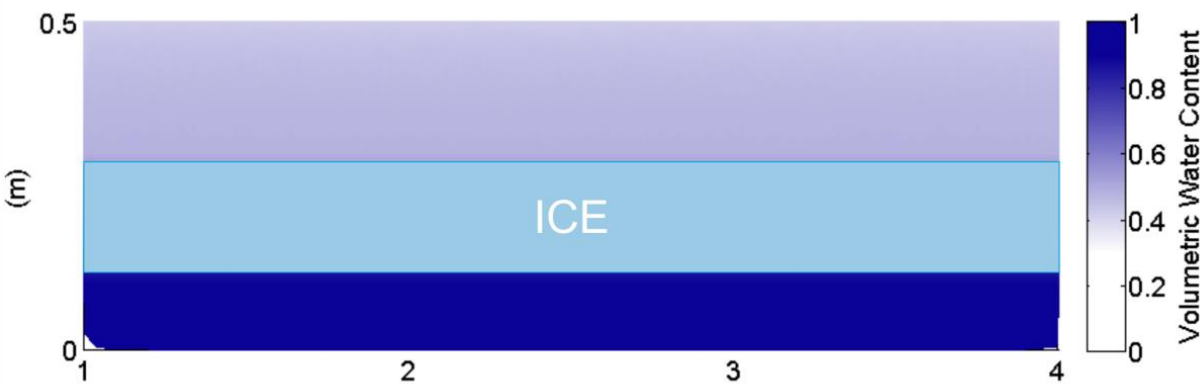

(m)

Figure 3 - Water balance in four different frost layer model scenarios after five weeks of diurnal evaporation. This shows breaks in the frost layer allow the evaporating surface to maintain connectivity to the falling water table below the ice, but there is limited lateral connectivity with little water supplied to areas not directly above the hole. 
Hydrol. Earth Syst. Sci. Discuss., https://doi.org/10.5194/hess-2017-678

Manuscript under review for journal Hydrol. Earth Syst. Sci.

Discussion started: 12 January 2018

\subsection{2-D model simulations (topography included)}

Hummock-hollow microtopography simulations show lateral water transfer between adjacent water conserving and productive zones that substantially influences GWC and associated wildfire severity. Although the spatial extent of lateral water transfer is limited, and its influence doesn't extend beyond $0.5 \mathrm{~m}$, this can induce strong spatial variability in

After 2 weeks After 5 weeks

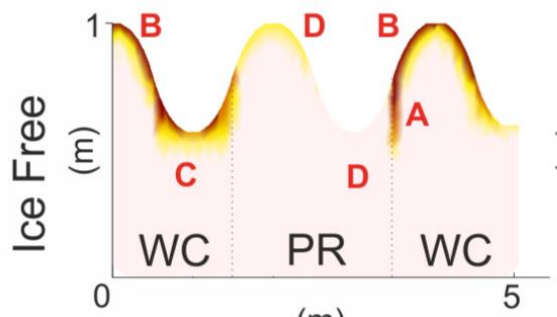

(m)

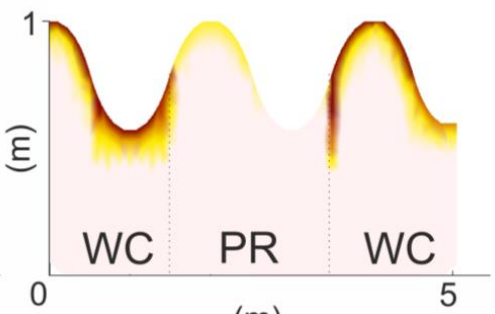

(m)

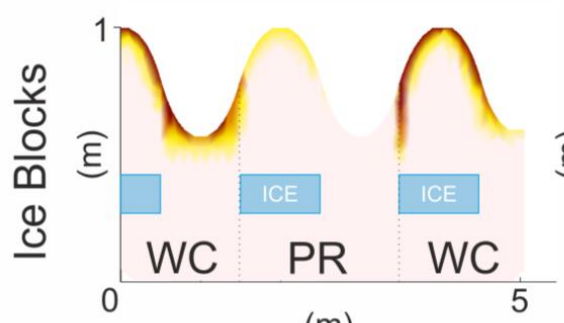

(m)

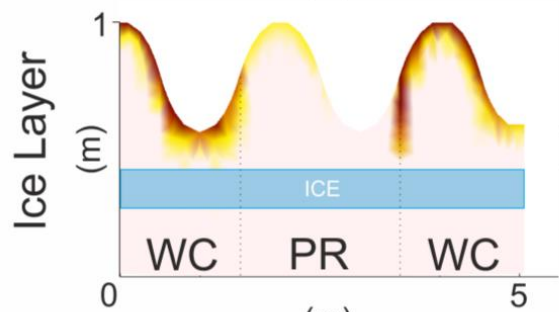

(m)

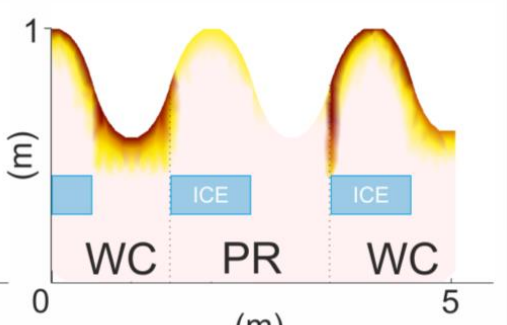

$(\mathrm{m})$

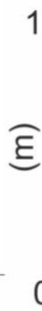

Figure 4 - Gravimetric water contents across modelled domains after two and five weeks of evaporation. WC $=$ Water conserving peat type, PR = Productive peat type. The water table intersects the frost layer on day 26 , as a result there are only minimal differences in water content distributions between the different ice scenarios after two weeks. For the results after five weeks, where the water table is below the level of the frost layer, the surface moisture content is partly determined by connectivity to the falling water table. This shows productive areas above solid ice will dry out substantially compared to the same areas over discontinuous or absent frost layers (See text for discussion of labels A-D). 
GWC (Figure 4). Lateral water transfer results in zones of low GWC typically at the sides of peat hummocks (one example labelled as " $\mathrm{A}$ " in Figure 4). These represent zones of high susceptibility to deep smouldering combustion and thus high burn severity.

Evaporation and GWCs of a given profile through the transect depends both on the hydraulic properties of the profile itself, and the hydraulic properties of adjacent areas. After two weeks of evaporation, the water table has not declined to the depth of the frost layer, thus the ice and ice-free scenarios behave similarly (Figure $4 \mathrm{a} / \mathrm{b}$ ). Areas of water conserving peat, which respond to evaporative stress with high surface tensions, have very low nearsurface GWCs. As such, water conserving hummocks exhibit GWCs $<250 \%$ at depths of $<0.03$ m (e.g. "B" in Figure 4). Similarly hollows have GWCs $<250 \%$ to a depth of $0.05 \mathrm{~m}$ (e.g. "C" in Figure 4). At depth within both hummocks and hollows, deeper peat has much higher GWC. Conversely, areas with productive peat facilitate the upwards movement of water from deeper in the peat, resulting in a more even vertical distribution of GWC (e.g. "D" in Figure 4). This results in higher GWC at the near-surface of productive hummocks compared to water conserving hummocks. In productive hollows, this results in higher water contents at the near-surface and lower water contents at depth.

Five weeks into the simulation, GWC varies little between the frost free and broken frost layer scenarios (Figure 4); however, the scenario with a solid frost layer, shows that the GWCs of hollows are substantially lower compared to the other ice scenarios and the same ice scenario after three weeks (Figure 4). In productive hollows, after five weeks (labelled "E" in Figure 4), the surface GWC is $400 \%$, compared $800 \%$ for the no ice scenario. In water conserving hollows surface water contents are similar for all ice scenarios.

Interactions between adjacent water conserving and productive areas create small regions of enhanced heterogeneity in GWC (labelled " $\mathrm{A}$ " in Figure 4). In the case of a water conserving hummock next to a productive hollow, water is drawn out of the side of the hummock and a region of very low GWC develops at the margin of the water conserving area. This region of low GWC is affected by the presence of a solid frost layer, with the area being slightly larger for the solid ice scenario compared to the other two scenarios after three weeks and substantially larger and also of much lower GWCs after five weeks (Figure 4). 
Hydrol. Earth Syst. Sci. Discuss., https://doi.org/10.5194/hess-2017-678

Manuscript under review for journal Hydrol. Earth Syst. Sci.

Discussion started: 12 January 2018

(C) Author(s) 2018. CC BY 4.0 License.
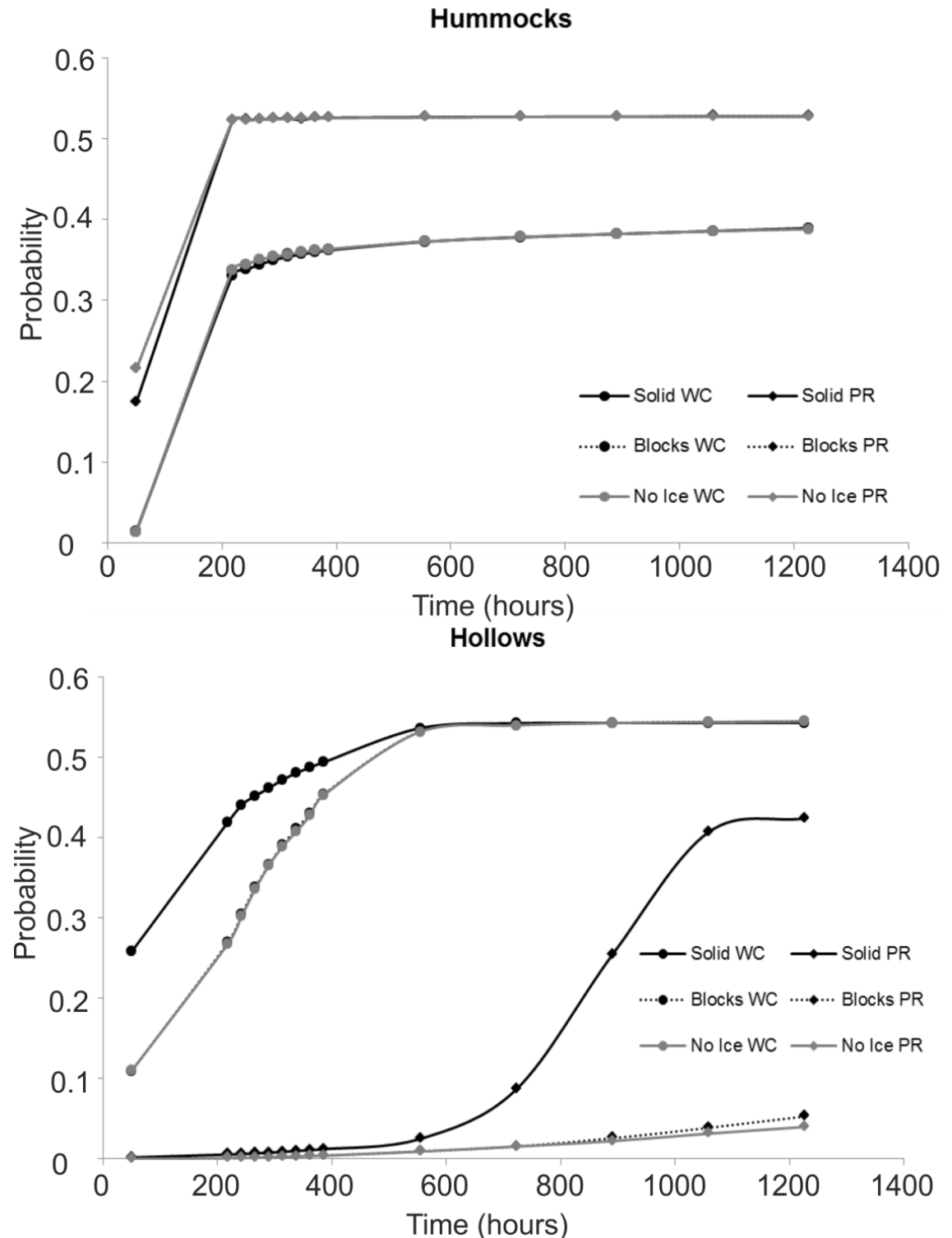

Figure 5 - The probability of ignition (gravimetric water content is lower than $250 \%$ ), for near-surface peat, over time for the different microtopographic areas and hydraulic properties (PR - Productive peat properties, WC - Water conserving peat properties)

For hummocks, all scenarios show very little change in surface water content over the model 
Hydrol. Earth Syst. Sci. Discuss., https://doi.org/10.5194/hess-2017-678

Manuscript under review for journal Hydrol. Earth Syst. Sci.

Discussion started: 12 January 2018

distribution of peat densities using Eq. (8). Results are displayed as the probability of GWC being lower than $250 \%$, representing a threshold for smouldering. All scenarios show similar hummock probabilities over time for both hydraulic properties types (Figure 5A), indicating the presence of a solid frost layer has only a small influence on hummock GWC. Conversely solid ice has a substantial effect on hollow GWC (Figure 5B). In productive peat hollows probabilities rise steeply two weeks into the simulation and the ice free and ice block
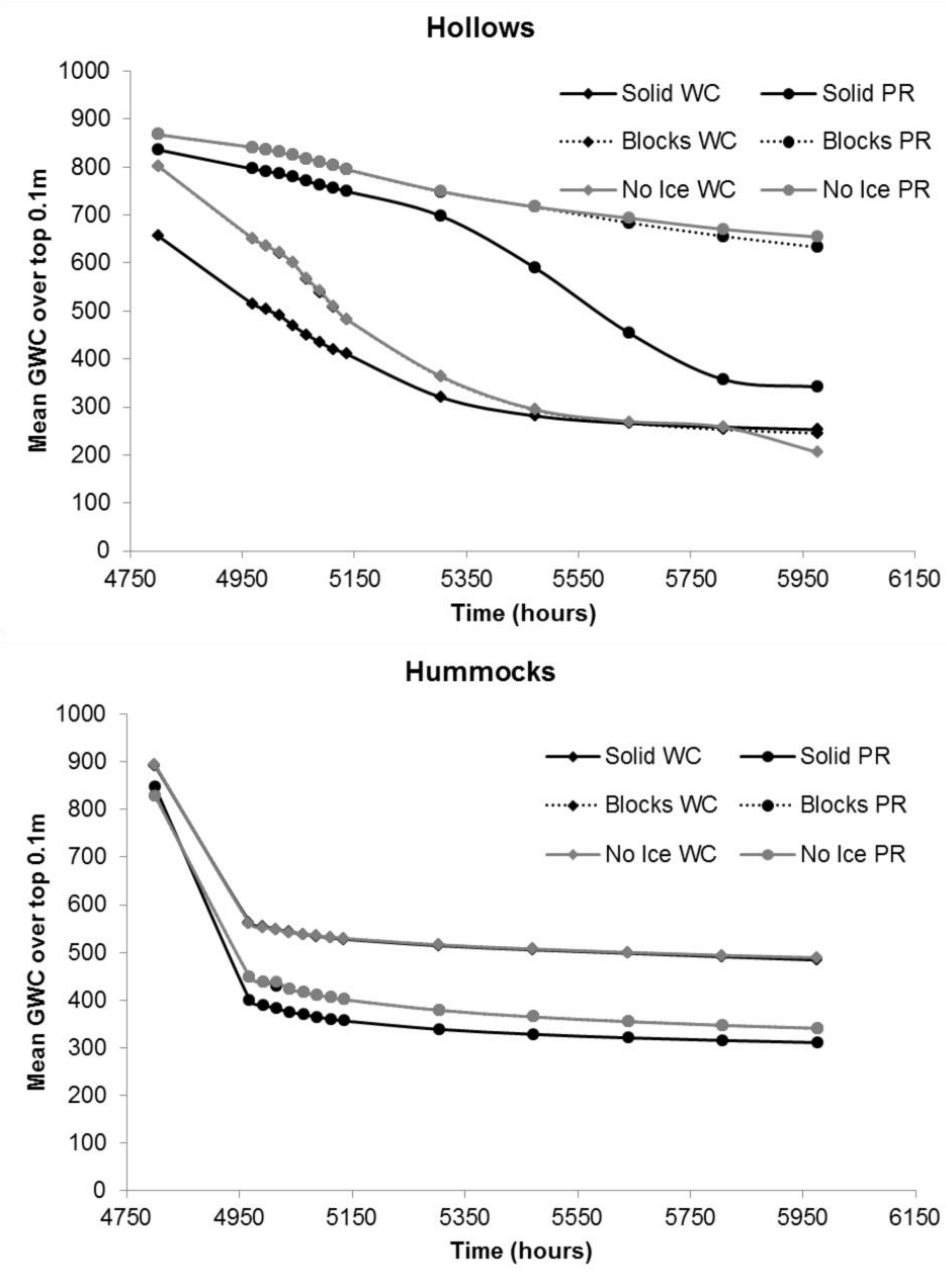

408

Figure 6 - Mean gravimetric water content over the top $0.1 \mathrm{~m}$ of the profile for different microtopographic features showing how vunerability to deeper smouldering varies over time for different scenarios and features.

scenarios diverge (Figure 5B). Mean GWC over the top $0.10 \mathrm{~m}$ of the peat profile (Figure 6)

shows a similar pattern to Figure 5. Hummock GWC is relatively insensitive to ice scenario, 

compared to other scenarios (Figure 6A).

\section{Discussion}

Our results show that seasonal frost layers can affect near-surface GWC and thus the vulnerability of peat to smouldering during wildfires. However, this increased vulnerability probability is also dependent on peat hydrological properties and microtopographical position.

\subsection{Peatland vadose zone hydrology in presence of ice}

In common with other studies, numerical modelling herein demonstrates that peat hydraulic properties exert a primary control on near-surface water contents (Kettridge et al., 2015a;McCarter and Price, 2014;Dixon et al., 2017). Notably, simulations indicate presence or absence of a frost layer has a minimal effect on the water balance for peat hydraulic properties which restrict the unsaturated water flow, and thus limit evaporation (water conserving). In such case, a drier near-surface peat layer developed with volumetric water contents of $\theta=0.30-0.50$ in the upper $0.05 \mathrm{~m}$. However, below $0.10 \mathrm{~m}$ depth, peat remained saturated over multiple weeks of evaporation (Figure 2). Therefore, even after six weeks of evaporation, the water table remains at a depth no greater than $0.15 \mathrm{~m}$, which is higher than the observed spring depth of ice in boreal peatlands (Figure 2, and Petrone et al., 2008). Conversely, for peats that facilitate unsaturated water flow from depth to the evaporating surface (productive), ice has a substantial effect on water contents. Although productive peat readily supplies water to the evaporating surface and maintains a wetter near-surface (Figure 2), greater evaporation, compared to water conserving peat, drove a rapid fall in the water table and, subsequently lowered water contents at depth. In situations where productive peat is underlain by a solid frost layer, the water table dropped to the level of the ice, and subsequently the peat above of the frost layer continued to dry out with further evaporation (Figure 3). Although surface tensions rose during drying in the layer above the ice these did not become high enough to begin to limit evaporation until the peat at $0.15 \mathrm{~m}$ depth had a water content of $\theta=0.60$ and evaporation persisted even with $\theta=0.45$.

Horizontal gaps in the frost layer allow the evaporating surface to maintain hydrological connectivity with the falling water table and thus avoid productive peat drying out (Figures 2 
and 4). However, the primary unsaturated flow direction from depth is vertical and there is limited lateral flow away from the frost gap. This results in heterogeneity of near-surface water contents with areas directly above the frost gap maintaining near-surface water contents similar to frost free scenarios, whereas more distant areas dry out to the same extent as solid frost layer scenarios (Figures 2 and 3).

Where peat hydraulic properties are varied across a hummock-hollow microtopography sequence water balance patterns become more complex compared to a planar atmospheric boundary (Figure 3). As with a flat atmospheric boundary, water conserving hollows are characterised by a very dry near-surface (upper $0.05 \mathrm{~m}$ ), but with much higher water contents at depths of greater than $0.1 \mathrm{~m}$. Conversely, productive hollows are able to maintain high near-surface volumetric water contents and maintain hydrological connectivity with a falling water table. As with the planar surface scenarios the transfer of water from depth through the frost gap is primarily vertical, with little lateral transfer of water away from the gap. The combination of a discontinuous frost layer with variations in peat hydraulic properties across a hummock-hollow microtopography leads to a high degree of heterogeneity in volumetric and gravimetric water contents.

It is important to note however that our initial model conditions assume near saturation following spring snow melt above the frost layer. The system is thus relatively wet, with a shallow starting water table. A drier set of initial conditions, either as a result of different hydrogeological conditions, a drier autumn period leaving the soil drier before winter, or a smaller snowmelt recharge, would mean a lower starting water table and, therefore, an increased probability that the water table will reach the frost layer, as observed by Petrone et al [2008]. We also assume the frost layer does not thaw during the model runs and thus does not provide water recharge, which is calculated as approximately $1.8 \mathrm{~mm} /$ day. We assume a fixed daily evaporation rate of $4.5 \mathrm{~mm} /$ day; this is a fairly high rate, however, Sphagnum evapotranspiration rates can reach an average of $0.47 \mathrm{~mm} / \mathrm{hr}$, and unlike systems which show highest ET rates coincident with highest air temperatures, Alberta peatlands show peak ET rates during the early growing season as frozen soil is thawing (Brown et al., 2010), which is the period being modelled. Finally, the critical surface tension threshold (hCritA) 
which shuts off evaporation, here a fixed value of $400 \mathrm{mb}$ after McCarter and Price (2014), needs to be considered. It is reasonable to assume the true value of hCritA will vary with relatively humidity and may in fact be higher at some points during the model runs which represent prolonged rain free periods. As a result, the model scenarios may underestimate total evaporation, but overestimate the drying given the lack of thawing frost recharge. However, all these assumptions (no thaw, evaporation rate, hritA and initial conditions) are within 1-2 mm/day, and are constant between scenarios.

Considering these assumptions, we restrict ourselves to exploring relative comparisons in VWC and GWC between the modelling scenarios, rather than use modelling results to deliver quantitative predictions. The overall effect of our modelling assumptions is likely to mean that for a given real peatland the time taken to reach a given point in the results may be under or overestimated, but the overall pattern of behaviour is likely to be consistent as this is governed by the peat hydrological properties. If more water is lost through evaporation (higher evaporation rate or dynamic HcritA), or the initial conditions are drier, then the water table will recede to a deeper level earlier and the near-surface GWCs will fall earlier. Conversely, if the recharge from thawing frost is accounted for under the same evaporative and initial conditions the water table recession will be slower and it will take longer for the near-surface GWCs to fall.

\subsection{Implications for peatland wildfire burn severity}

Our results suggest that seasonal frost has a pronounced effect on potential burn depths in boreal peatlands during periods of pronounced drying. Regardless of the type of peat properties, the frost table makes near-surface peat layers, particularly in hollows, more vulnerable to wildfire (smouldering) following a multi-week period without rain by reducing near-surface moisture contents. Given that burn severity in peatlands is highly heterogeneous (Lukenbach et al., 2016), seasonal frost dynamics along with peat hydraulic properties may help explain why some hummocks (or hollows) burn more severely than others. Specifically, the uneven thawing of ice in spring may drive heterogeneity in connectivity to the water table and facilitate variations in near-surface GWC. Pronounced variability in burn severity within microform types has been observed (Lukenbach et al., 
2015a, 2016), and these results illustrate hydrological mechanisms beyond peat properties which can drive variability in the probability of peat ignition during wildfire.

The probability that gravimetric water contents are lower than a critical smouldering threshold of $\sim 250 \%$ (c.f. Thompson et al., 2015;Zoltai et al., 1998;Lukenbach et al., 2015b;Benscoter et al., 2011) are higher when a frost layer was present compared to when it was absent, and was most pronounced for areas with productive peat hydraulic properties (Figures 5). The most sensitive sub-set is productive hollows, where the presence of a frost layer substantially increases the probability that near-surface GWC drops below $250 \%$ (Figure 5) and also lowers the average GWC over the top $0.1 \mathrm{~m}$ of the profile (Figure 6). Our results indicate that ice free conditions coinciding with a prolonged rain free period in peatland would result in approximately $50 \%$ of hummocks being vulnerable to smouldering combustion (Figure 5A), with approximately $25 \%$ of hollows vulnerable to smouldering combustion and potentially deep depths of burn (Figure 5B). In the presence of a solid frost layer, however, the proportion of hollows vulnerable to appreciable smouldering depths rises to around 50\% (Figure 6B), effectively doubling the extent of deeper depth of burn. Heightened heterogeneity in water content can occur when adjacent areas have different hydraulic properties. A wedge of low GWC develops where either a water conserving hummock is next to a productive hollow, or a productive hummock is adjacent to a water conserving hollow (labelled as " $\mathrm{A}$ " in Figure 4). Results also indicate that although hummocks are much higher above the water table, they are able to retain a moist vadose zone (e.g. Benscoter and Wieder, 2003;Thompson and Waddington, 2013;Shetler et al., 2008;Lukenbach et al., 2015b;Benscoter et al., 2011) and are to an extent hydrologically disconnected from the water table with surface water balance dependant on water retained within the hummock; this means they are characterised by a very dry near-surface, but a moist enough interior of the hummock that GWCs offer protection against deep smouldering, regardless of the presence or absence of a frost layer.

An interesting implication of these results is that productive hummocks may be better able to maintain higher near-surface GWCs and thus resist smouldering combustion; this would mean that they are better placed to recover quickly from wildfires (Lukenbach et al., 2015a, 
2016). Conversely, more water conserving hummocks may be susceptible to higher burn severity due to their very dry near-surface, and may then be unable to recover quickly postfire or continue to conserve water (Lukenbach et al., 2016, 2015a). The presence of seasonal frost layers changes the implications of burn severity and recovery and introduces a trade off in the optimum peat profiles. For hollows, a water conserving peat would be slower growing and experience more frequent periods of water stress, however when ice is present it will be characterised by a thin, dry layer above a relatively moist layer which may restrict smouldering to a thin surface band of peat and promote more rapid recovery post-fire. Conversely, hollows with productive peat will be able to buffer periods of water stress and will be faster growing, however, they will be vulnerable to drying out in the presence of a frost layer, meaning they could be subject to high burn severity and then take a long time to subsequently recover ecohydrological function.

\section{Conclusions}

Two dimensional numerical modelling results show that seasonal frost layers can play an important role in disconnecting the evaporating surface of the peatland from the deeper water table and so can enhance heterogeneity in near-surface water contents, which likely influences patterns of ignition and burn severity during wildfire. In common with other studies, we find peat hydraulic properties provide an important control on peat water balance, as they control the ability of the peat to transmit water from deeper saturated layers to the evaporating surface. Hummock microforms are typically higher above the water table and so over seasonal timescales do not depend on direct connection to the deep water table to supply evaporative demand, rather they utilise water stored in a large unsaturated mass of the hummock. As a result of their decreased dependence on connection to the water table, hummock microforms are relatively unaffected by the presence of a seasonal frost layer. Conversely, hollow microforms depend to a greater degree on maintaining connectivity to the water table in order to supply water to meet evaporative demand. Hollows which tend towards water conserving are less able to transmit water from deeper saturated layers will tend to dry out at the very near-surface, but maintain high tensions and pressure gradients to layers with higher water contents immediately below. In prolonged rain free periods, regardless of seasonal ice presence, these areas are therefore vulnerable to deep smouldering in wildfire. Conversely, hollows comprised of peat which tends towards greater production 
Hydrol. Earth Syst. Sci. Discuss., https://doi.org/10.5194/hess-2017-678

Manuscript under review for journal Hydrol. Earth Syst. Sci.

Discussion started: 12 January 2018

(c) Author(s) 2018. CC BY 4.0 License.

569 and water use, are highly dependent on seasonal ice presence. Productive hollows will dry

570 out in the presence of a seasonal frost layer as their surface is disconnected from the water

571 table. In addition, they are able to maintain productivity, and evaporation, in the presence of

572 low water contents, and therefore can be subjected to substantial drying. This substantial

573 drying will make the area vulnerable to deep burning in wildfires. At the landscape scale

574 our results show the presence of a frost layer with a prolonged rain free period will increase

575 the proportion of hollows vulnerable to deeper burning $(>0.1 \mathrm{~m})$ from $25 \%$ to $50 \%$. The high

576 degree of natural variability in peat hydraulic properties will lead to a high degree of

577 heterogeneity in near-surface water contents during rain free periods, and thus

578 heterogeneity in wildfire burning within microform type. The presence of a seasonal frost

579 layer both raises the overall risk of smouldering and deeper burning $(>0.1 \mathrm{~m})$ during

580 wildfires, but also enhances the degree of heterogeneity. 
Hydrol. Earth Syst. Sci. Discuss., https://doi.org/10.5194/hess-2017-678

Manuscript under review for journal Hydrol. Earth Syst. Sci.

Discussion started: 12 January 2018

(c) Author(s) 2018. CC BY 4.0 License.
Hydrology and

Earth System

Sciences

Discussions

Baird, A. J., Eades, P. A., and Surridge, B. W. J.: The hydraulic structure of a raised bog and its implications for ecohydrological modelling of bog development, Ecohydrology, 1, 289-298, 2008.

Baird, A. J., Milner, A. M., Blundell, A., Swindles, G. T., and Morris, P. J.: Microformscale variations in peatland permeability and their ecohydrological implications, Journal of Ecology, 104, 531-544, 10.1111/1365-2745.12530, 2016.

Beckwith, C. W., Baird, A. J., and Heathwaite, A. L.: Anisotropy and depth - related heterogeneity of hydraulic conductivity in a bog peat. I: laboratory measurements, Hydrological processes, 17, 89-101, 2003.

Benscoter, B. W., and Wieder, R. K.: Variability in organic matter lost by combustion in a boreal bog during the 2001 Chisholm fire, Canadian Journal of Forest Research, 33, 25092513, 10.1139/x03-162, 2003.

Benscoter, B. W., Thompson, D. K., Waddington, J. M., Flannigan, M. D., Wotton, B. M., De Groot, W. J., and Turetsky, M. R.: Interactive effects of vegetation, soil moisture and bulk density on depth of burning of thick organic soils, International Journal of Wildland Fire, 20, 418-429, 2011.

Boelter, D. H.: Hydraulic conductivity of peats, Soil Science, 100, 227-231, 1965.

Branham, J. E., and Strack, M.: Saturated hydraulic conductivity in Sphagnum dominated peatlands: do microforms matter?, Hydrological Processes, 28, 4352-4362, 2014.

Brown, S. M., Petrone, R. M., Mendoza, C., and Devito, K. J.: Surface vegetation controls on evapotranspiration from a sub - humid Western Boreal Plain wetland, Hydrological Processes, 24, 1072-1085, 10.1002/hyp.7569, 2010.

Devito, K. J., Mendoza, C. A., and Qualizza, C.: Conceptualizing water movement in the Boreal Plains. Implications for watershed reconstruction. Synthesis report prepared for the Canadian Oil Sands Network for Research and Development, Environmental and Reclamation Research Group, 164, 2012.

Dixon, S. J., Kettridge, N., Moore, P. A., Devito, K. J., Tilak, A. S., Petrone, R. M., Mendoza, C. A., and Waddington, J. M.: Peat depth as a control on moss water availability under evaporative stress, Hydrological Processes, 31, 4107-4121, 10.1002/hyp.11307, 2017.

Flannigan, M. D., Logan, K. A., Amiro, B. D., Skinner, W. R., and Stocks, B.: Future area burned in Canada, Climatic change, 72, 1-16, 2005. 
Hydrol. Earth Syst. Sci. Discuss., https://doi.org/10.5194/hess-2017-678

Manuscript under review for journal Hydrol. Earth Syst. Sci.

Discussion started: 12 January 2018

(c) Author(s) 2018. CC BY 4.0 License.
Hydrology and

Earth System

Sciences

Discussions

Frolking, S., and Roulet, N. T.: Holocene radiative forcing impact of northern peatland carbon accumulation and methane emissions, Global Change Biology, 13, 1079-1088, 2007.

Gorham, E.: Northern peatlands: role in the carbon cycle and probable responses to climatic warming, Ecological applications, 1, 182-195, 1991.

Hogan, J. M., Van der Kamp, G., Barbour, S. L., and Schmidt, R.: Field methods for measuring hydraulic properties of peat deposits, Hydrological processes, 20, 3635-3649, 2006.

Hokanson, K. J., Lukenbach, M. C., Devito, K. J., Kettridge, N., Petrone, R. M., and Waddington, J. M.: Groundwater connectivity controls peat burn severity in the boreal plains, Ecohydrology, 9, 574-584, 10.1002/eco.1657, 2016.

Kasischke, E. S., and Turetsky, M. R.: Recent changes in the fire regime across the North American boreal region - spatial and temporal patterns of burning across Canada and Alaska, Geophysical research letters, 33, 2006.

Kennedy, G. W., and Price, J. S.: A conceptual model of volume-change controls on the hydrology of cutover peats, Journal of Hydrology, 302, 13-27, 2005.

Kettridge, N., Tilak, A. S., Devito, K. J., Petrone, R. M., Mendoza, C. A., and Waddington, J. M.: Moss and peat hydraulic properties are optimized to maximize peatland water use efficiency, Ecohydrology, 2015a.

Kettridge, N., Turetsky, M. R., Sherwood, J. H., Thompson, D. K., Miller, C. A., Benscoter, B. W., Flannigan, M. D., Wotton, B. M., and Waddington, J. M.: Moderate drop in water table increases peatland vulnerability to post-fire regime shift, Scientific reports, 5, $2015 b$.

Lewis, C., Albertson, J., Xu, X., and Kiely, G.: Spatial variability of hydraulic conductivity and bulk density along a blanket peatland hillslope, Hydrological Processes, 26, 1527-1537, 10.1002/hyp.8252, 2012.

Lukenbach, M. C., Devito, K. J., Kettridge, N., Petrone, R. M., and Waddington, J. M.: Hydrogeological controls on post-fire moss recovery in peatlands, Journal of Hydrology, 530, 405-418, http://dx.doi.org/10.1016/j.jhydrol.2015.09.075, 2015a.

Lukenbach, M. C., Hokanson, K. J., Moore, P. A., Devito, K. J., Kettridge, N., Thompson, D. K., Wotton, B. M., Petrone, R. M., and Waddington, J. M.: Hydrological 
Hydrol. Earth Syst. Sci. Discuss., https://doi.org/10.5194/hess-2017-678

Manuscript under review for journal Hydrol. Earth Syst. Sci.

Discussion started: 12 January 2018

(c) Author(s) 2018. CC BY 4.0 License.
Hydrology and

Earth System

Sciences

Discussions

(c) (1)

642

643

644

645

646

647

648

649

650

651

652

653

654

655

656

657

controls on deep burning in a northern forested peatland, Hydrological Processes, 29, 41144124, 10.1002/hyp.10440, 2015 b.

Lukenbach, M. C., Devito, K. J., Kettridge, N., Petrone, R. M., and Waddington, J. M.:

Burn severity alters peatland moss water availability: Implications for post-fire recovery, Ecohydrology, 9, 341-353, 2016.

McCarter, C. P. R., and Price, J. S.: Ecohydrology of Sphagnum moss hummocks: mechanisms of capitula water supply and simulated effects of evaporation, Ecohydrology, 7, 33-44, 2014.

McCauley, C. A., White, D. M., Lilly, M. R., and Nyman, D. M.: A comparison of hydraulic conductivities, permeabilities and infiltration rates in frozen and unfrozen soils, Cold Regions Science and Technology, 34, 117-125, http://dx.doi.org/10.1016/S0165232X(01)00064-7, 2002.

Petrone, R. M., Devito, K. J., Silins, U., Mendoza, C. A., Brown, S. C., Kaufman, S. C., and Price, J. S.: Transient peat properties in two pond-peatland complexes in the sub-humid Western Boreal Plain, Canada, Mires \& Peat, 3, 2008.

Prat-Guitart, N., Rein, G., Hadden, R. M., Belcher, C. M., and Yearsley, J. M.: Propagation probability and spread rates of self-sustained smouldering fires under controlled moisture content and bulk density conditions, International Journal of Wildland Fire, 25, 456-465, https://doi.org/10.1071/WF15103, 2016.

Quinton, W. L., Hayashi, M., and Carey, S. K.: Peat hydraulic conductivity in cold regions and its relation to pore size and geometry, Hydrological Processes, 22, 2829-2837, 10.1002/hyp.7027, 2008.

Roulet, N., Moore, T., Bubier, J., and Lafleur, P.: Northern fens: methane flux and climatic change, Tellus B, 44, 100-105, 1992.

Sherwood, J. H., Kettridge, N., Thompson, D. K., Morris, P. J., Silins, U., and Waddington, J. M.: Effect of drainage and wildfire on peat hydrophysical properties, Hydrological Processes, 27, 1866-1874, 2013.

Shetler, G., Turetsky, M. R., Kane, E. S., and Kasischke, E. S.: Sphagnum mosses limit total carbon consumption during fire in Alaskan black spruce forests, Canadian Journal of Forest Research, 38, 2328-2336, 2008. 
Hydrol. Earth Syst. Sci. Discuss., https://doi.org/10.5194/hess-2017-678

Manuscript under review for journal Hydrol. Earth Syst. Sci.

Discussion started: 12 January 2018

(c) Author(s) 2018. CC BY 4.0 License.
Hydrology and

Earth System

Sciences

Discussions

Šimůnek, J., Šejna, M., and Van Genuchten, M. T.: The HYDRUS-2D software package for simulating the two-dimensional movement of water, heat, and multiple solutes in variably-saturated media: version 2.0, US Salinity Laboratory, Agricultural Research Service, US Department of Agriculture, 1999.

Smith, L. C., MacDonald, G. M., Velichko, A. A., Beilman, D. W., Borisova, O. K., Frey, K. E., Kremenetski, K. V., and Sheng, Y.: Siberian peatlands a net carbon sink and global methane source since the early Holocene, Science, 303, 353-356, 2004.

Stocks, B. J., Mason, J. A., Todd, J. B., Bosch, E. M., Wotton, B. M., Amiro, B. D., Flannigan, M. D., Hirsch, K. G., Logan, K. A., and Martell, D. L.: Large forest fires in Canada, 1959-1997, Journal of Geophysical Research: Atmospheres, 107, 2002.

Thompson, D. K., and Waddington, J. M.: Wildfire effects on vadose zone hydrology in forested boreal peatland microforms, Journal of hydrology, 486, 48-56, 2013.

Thompson, D. K., Wotton, B. M., and Waddington, J. M.: Estimating the heat transfer to an organic soil surface during crown fire, International Journal of Wildland Fire, 24, 120129, 2015.

Turetsky, M. R., Wieder, K., Halsey, L., and Vitt, D.: Current disturbance and the diminishing peatland carbon sink, Geophysical Research Letters, 29, 2002.

Turetsky, M. R., Amiro, B. D., Bosch, E., and Bhatti, J. S.: Historical burn area in western Canadian peatlands and its relationship to fire weather indices, Global Biogeochemical Cycles, 18, 2004.

Turetsky, M. R., Kane, E. S., Harden, J. W., Ottmar, R. D., Manies, K. L., Hoy, E., and Kasischke, E. S.: Recent acceleration of biomass burning and carbon losses in Alaskan forests and peatlands, Nature Geoscience, 4, 27-31, 2011.

Van Genuchten, M. T.: A closed-form equation for predicting the hydraulic conductivity of unsaturated soils, Soil science society of America journal, 44, 892-898, 1980.

Wieder, R. K., Scott, K. D., Kamminga, K., Vile, M. A., Vitt, D. H., Bone, T., Xu, B., Benscoter, B. W., and Bhatti, J. S.: Postfire carbon balance in boreal bogs of Alberta, Canada, Global Change Biology, 15, 63-81, 2009.

Yu, Z., Loisel, J., Brosseau, D. P., Beilman, D. W., and Hunt, S. J.: Global peatland dynamics since the Last Glacial Maximum, Geophysical Research Letters, 37, 2010. 
Hydrol. Earth Syst. Sci. Discuss., https://doi.org/10.5194/hess-2017-678

Manuscript under review for journal Hydrol. Earth Syst. Sci.

Discussion started: 12 January 2018

(c) Author(s) 2018. CC BY 4.0 License.

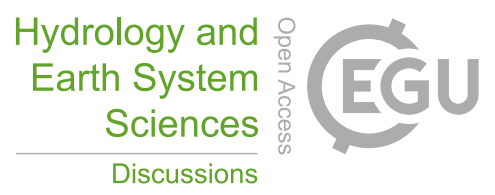

(c) (1)

703 carbon cycling in North American boreal peatlands, Environmental Reviews, 6, 13-24,

704 10.1139/a98-002, 1998.

705 